DOI 10.4467/2543733XSSB.17.007.7253

ANDRZEJ DUBICKI

Uniwersytet Łódzki

\title{
WSPÓLPRACA POLSKO-RUMUŃSKA W RAMACH RWPG DO ROKU 1962 (DO XVI SESJI RWPG)
}

Słowa kluczowe: Polska, Rumunia, RWPG, stosunki gospodarcze

Współpraca poddana analizie w niniejszym artykule będzie się koncentrowała na latach 1949-1962. Cezurę początkową symbolicznie otwiera utworzenie RWPG w 1949 roku, choć oczywiście należy też brać pod uwagę wcześniejsze wydarzenia w polityce gospodarczej oraz historii, które doprowadziły do powstania tej organizacji międzynarodowej. Cezurę końcową będzie stanowił rok 1962, dokładnie XVI Sesja RWPG, czyli czas, w którym Rumunia w odpowiedzi na sugestię strony polskiej nie zgodziła się na dalsze zacieśnianie współpracy w ramach organizacji, przynajmniej w stosunku do prób wymuszonego odgórnie podziału produkcji, co z kolei będzie stanowiło istotną cezurę w dziejach Rumunii, nie tylko pod względem gospodarczym, ale i w dużej mierze politycznym, bowiem ten moment uznaje się w odniesieniu do Bukaresztu za początek propagowania tam rodzimej wersji komunizmu - czyli komunizmu o charakterze narodowym, u źródeł którego leżał brak zgody reżimu Gheorghe Gh. Deja na propozycje dalszego zacieśniania współpracy w ramach RWPG, co oznaczałoby de facto upośledzenie Rumunii i zamknięcie jej drogi do forsownej industrializacji ${ }^{1}$.

Dzieje RWPG można za Andrzejem Skrzypkiem podzielić na cztery okresy: pierwszy, wstępny obejmujący lata 1949-1953; drugi (1954-1962), w którym organizacja zajmowała się przede wszystkim ustabilizowaniem rozwoju państw socjalistycznych. Okres ten trwał do roku 1962 i zawierał w sobie następujące „kamienie milowe” dla organizacji:

- 1956: utworzenie komisji rzeczowych Rady;

- 1959: nadanie Radzie statusu prawnego;

- 1962: utworzenie Komitetu Wykonawczego; wyjście poza stary kontynent, powołanie komisji problemowych ${ }^{2}$.

${ }^{1}$ M. Marin, The Nationalistic Discourse in Communist Romania. A General Perspective, Studia Universitatis Babes Bolyai. Historia, 2/2011, s. 81.

${ }^{2}$ A. Skrzypek, Etapy rozwoju Rady Wzajemnej Pomocy Gospodarczej, [w:] 40 lat rozwoju RWPG. Ewolucja instytucji i struktur socjalistycznej integracji gospodarczej, Warszawa 1988, s. 18. 
Okres trzeci i czwarty nie stanowią już przedmiotu analizy niniejszego opracowania, niemniej należy zaznaczyć, że trwają one odpowiednio, trzeci w latach 1965-1985, gdzie cezurą końcową będzie ogłoszenie pieriestrojki przez M. Gorbaczowa, natomiast czwarty, który okazał się schyłkowy zarówno dla RWPG, jak i innych organizacji politycznych tzw. drugiego świata, obejmuje lata 1985-1991.

W nauce rumuńskiej stosowany jest nieco inny podział czasowy. Pierwszy okres obejmuje lata 1949-1959, czyli okres ewolucji tej organizacji: od przybudówki do kreowanej przez ZSRR polityki gospodarczej do pełnoprawnej organizacji międzynarodowej. W tym czasie RWPG była instrumentem koordynacji polityki ekonomicznej, tak aby konkurować z krajami kapitalistycznymi - być w stanie rywalizować z grupą krajów uczestniczących w Planie Marshalla. Pewna ewolucja nastąpiła już w 1954 roku z uwagi na zmiany zachodzące w ZSRR po śmierci Stalina, ale także okrzepnięcie gospodarcze krajów organizacji i, jak to wówczas określano, zanik niebezpieczeństwa marshalizacji tych krajów. Kolejny wreszcie okres rozpoczyna się w roku 1959, co zostało symbolicznie zapoczątkowane przyjęciem statutu przez organizację. Deklarując wówczas zaniechanie rywalizacji z obozem kapitalistycznym, opowiadano się za walką o utrzymanie zasad ONZ i wspólną pracą w celu osiągnięcia lepszych wyników gospodarczych. Ważnym elementem zapisanym w statucie RWPG, z którego realizacją nie było z reguły najlepiej, była równość wszystkich członków organizacji. Kluczowe w tej sprawie, zwłaszcza w pierwszym okresie, było stanowisko NRD i Czechosłowacji, czyli krajów dość dobrze rozwiniętych, które nie były zbyt skore do dzielenia się pomocą z krajami słabiej rozwiniętymi, ponieważ uznawały to za zbytnie obciążenie dla własnej gospodarki ${ }^{3}$. Paradoksalnie dość kontrowersyjne okazało się, względnie mocno akcentowane (przeciw Zachodowi) w pierwszym okresie istnienia RWPG przez obóz wschodni, pryncypium niemieszania się w wewnętrzne sprawy innych państw. Później również zaczęło to być wykorzystywane w bloku wschodnim jako element obrony, np. przed zbyt daleko idącymi pomysłami integracji ekonomicznej.

Stosunki gospodarcze polsko-rumuńskie, rozwijające się w mniej lub bardziej ożywiony sposób (w zależności od koniunktury na rynkach międzynarodowych) w okresie międzywojennym ${ }^{4}$, w nowych warunkach geopolitycznych nie straciły znaczenia, niemniej jednak w pierwszym okresie po zakończeniu II wojny światowej, który dość górnolotnie był określany jako walka o utrwalenie władzy ludowej, nie były zbyt intensywne. Wpływała na to przede wszystkim sytuacja gospodarcza i polityczna obu krajów, wynikająca z innego rodzaju obecności sowieckiej na konkretnym obszarze. O ile w Polsce Sowieci przebywali oficjalnie jako sojusznicy, o tyle w Rumunii występowali w dwóch rolach: po pierwsze jako sojusznicy, zwłaszcza po przejęciu w marcu 1945 roku władzy przez lewicowy rząd Petru Grozy, oraz w charakterze mocarstwa okupacyjnego, pobierającego $\mathrm{z}$ terenu Rumunii wszystkie niezbędne środki do prowadzenia wojny, a także kontrolującego wszelką wymianę gospodarczą, zabezpieczającego wszelkie materiały strategiczne a conto przyszłych reparacji wojennych. Co zrozumiałe, przejęcie władzy przez rząd Grozy w marcu 1945 roku spotkało się z pozytywnym przyjęciem ze strony

${ }^{3}$ C. B rân du şa, Activitatea României in Consiliul de Ajutor Economic Reciproc (1949-1974), București 2012, s. 24.

${ }^{4} \mathrm{Na}$ ten temat patrz m.in.: M. Le c zy k, Stosunki gospodarcze polsko-rumuńskie w latach 1921-1939, Zeszyty Naukowe Wyższej Szkoły Gospodarstwa Krajowego w Kutnie, 2002, nr 4, s. 33-54. 
władz polskich, jednak wówczas nawiązanie i dalsze ułożenie stosunków było kwestią przyszłości, a sprawa ewentualnego partnerstwa pomiędzy obydwoma zainteresowanymi krajami była jeszcze odległa, przede wszystkim z uwagi na wspomnianą różnicę statusu międzynarodowego ${ }^{5}$. Na osłabienie potencjału wzajemnej wymiany handlowej dodatkowo wpływały sprawy związane ze zniszczeniami wojennymi (w obu przypadkach); w Rumunii doszła ekspansywna gospodarka wojenna i potrzeba jej rekonwersji na tory pokojowe, ponadto, jak już wspomniano, Rumunia była obciążona klauzulami ekonomicznymi układu o zawieszeniu broni, co więcej, trudności pogłębiła klęska suszy na przełomie lat 1945 i 19466. Pierwszą wzajemną umowę handlową zawarto 7 lipca 1945 roku, niemniej jednak z uwagi na niedługi okres, jaki upłynął od zakończenia działań bojowych, i związane z tym uwarunkowania polityczne i gospodarcze, wolumen wzajemnej wymiany był wówczas bardzo ograniczony. Taka sytuacja cechowała pierwszy okres współpracy wewnątrzblokowej. Co prawda podejmowano wówczas próby poszerzenia możliwości handlowych, starając się koordynować wzajemne zobowiązania i plany wytwórcze - takie działania były zauważalne np. w stosunkach polsko-czechosłowackich, wszakże nie przyniosły one znaczniejszych i bardziej wymiernych rezultatów ${ }^{7}$. Rachuby na nawiązanie/odnowienie szerszych stosunków gospodarczych z Zachodem spaliły na panewce w związku z odrzuceniem pod wpływem ZSRR uczestnictwa w Planie Marshalla. Jako substytut utraconych potencjalnie korzyści z tytułu nieodbudowania dawnych więzi gospodarczych zdecydowano się na próbę wykreowania ich namiastki w bloku wschodnim oraz przyjęcia w pewnym momencie zasady samowystarczalności blokowej.

Przyjęcie wspomnianego pryncypium jest różnie oceniane w literaturze przedmiotu. O ile rzeczywiście w samym 1948/1949 roku ZSRR prawdopodobnie mógł do pewnego stopnia rekompensować swym satelitom utracone potencjalne korzyści, o tyle w okresie późniejszym już takich możliwości nie miał, w związku z rozbudową potencjału gospodarczego poszczególnych krajów i ich wzrastającymi potrzebami, również natury inwestycyjnej ${ }^{8}$. Oczywiście osobnym zagadnieniem jest realna wartość wzajemnych obrotów handlowych pomiędzy krajami bloku wschodniego a ZSRR. W starszej literaturze podnoszono, z oczywistych względów, dużą wartość pomocy materiałowej uzyskiwanej z ZSRR, natomiast należy pamiętać, że z pewnością nie była ona bezinteresowna, bowiem np. Polska w zamian wysyłała na wschód węgiel po bardzo preferencyjnej cenie, niewątpliwie niepokrywającej nawet kosztów wydobycia. Jeszcze bardziej korzystne dla ZSRR były umowy gospodarcze z dawnymi sojusznikami III Rzeszy (Rumunią, Węgrami i Bułgarią), jako że ZSRR w dużej mierze kontrolował kluczowe zakłady przemysłowe i część przedsiębiorstw transportowych na wspomnianych obszarach ${ }^{9}$, sytuacja ta trwała do końca lat pięćdziesiątych XX wieku ${ }^{10}$.

\footnotetext{
${ }^{5}$ A. S ow iń s k a-K ru p k a, Stosunki polsko-rumuńskie 1945-1949, Warszawa 1985, s. 97.

${ }^{6}$ Ibidem.

${ }^{7}$ A. Marszałek, Integracja ekonomiczna krajów RWPG a stosunki międzynarodowe. Geneza niepowodzenia. Łódź 1991, s. 51.

${ }^{8}$ Oficjalnie pomoc udzieloną przez ZSRR szacuje się na 10 mld rubli, przy czym przede wszystkim wchodziła w to akcja kredytowa. T. D o r o t a, B. R e ut t, RWPG, geneza, działalność, perspektywy, Warszawa 1972, s. 89.

${ }_{9}^{9}$ A. Marszałek, op. cit., s. 52.

${ }^{10} \mathrm{~L}$. D olog a, Sovromurile sau cum a fost parazitata economia romaneasca; http://www.ziare.com/economie/economie-politica/sovromurile-sau-cum-a-fost-parazitata-economia-romaneasca-1033079, (dostęp 11 V 2016).
} 
Z tego powodu we wspomnianym okresie wzajemne kontakty gospodarcze nie były zbyt ożywione, a do wymienionych uwarunkowań należy dołożyć kolejną sprawę, mianowicie utratę wspólnej granicy, co zawsze stanowi fakt dodatkowo w sposób negatywny obciążający wymianę handlową pomiędzy zainteresowanymi krajami. Inną przyczyną stagnacji w handlu była ograniczona podaż towarów i ograniczone możliwości eksportowe, wynikające z wcześniej wspomnianych okoliczności. W dodatku ograniczenie wymiany powodował fakt, że już przed wojną obydwa państwa rozwijały właściwie te same gałęzie gospodarki, przez co nie były one wobec siebie komplementarne, a raczej konkurencyjne.

Pierwsze wstępne próby nawiązania kontaktów miały miejsce wiosną 1945 roku, w kontekście wizyty w Bukareszcie ministra pełnomocnego Rządu Tymczasowego J. Olszewskiego, który w odniesieniu do spraw gospodarczych zajmował się przede wszystkim organizacją tranzytu do Polski przez port w Konstancy pomocy przyznanej w ramach UNRRA. Transporty te przez Rumunię przejeżdżały od 30 kwietnia 1945 do 28 kwietnia 1946 roku, a ich kierunkiem oprócz Polski była także i Czechosłowacja. Nie obywało się $\mathrm{w}$ tym przypadku bez kłopotów, związanych z koniecznością np. uregulowania opłat przewozowych na korzyść CFR (koleje rumuńskie), które strona polska chciała prolongować w formie kredytu, co z kolei zawetował rumuński MSZ, uzależniając zgodę na takie działanie, zwłaszcza początkowo, od wznowienia stosunków dyplomatycznych pomiędzy obydwoma krajami (co ostatecznie nastąpiło 13 sierpnia 1945 roku). Wobec zachowawczego stanowiska polskiego MSZ w tej sprawie transport towarów do Polski przebiegał z problemami. Wszelkie nieporozumienia zostały, przynajmniej formalnie, zlikwidowane wraz z podpisaniem 10 września 1948 roku układu likwidacyjnego dotyczącego zakończenia kwestii reparacji i rewindykacji mienia polskiego z Rumunii.

W kwestiach dotyczących bezpośrednio wymiany stricte gospodarczej należy zauważyć, że pierwsza umowa handlowa w okresie powojennym została zawarta 7 lipca 1945 roku, niemniej jednak była ona bardzo ograniczona, zresztą i w następnych latach wymiana towarowa rozwijała się bardzo wolno, tak że poziom z 1938 roku, i tak niewielki i będący jedynie ułamkiem rekordowych obrotów notowanych w latach dwudziestych, osiągnięto w 1948 roku$^{11}$.

Wspomniane zawarcie układu likwidacyjnego otworzyło drogę do przyjęcia układu o przyjaźni, współpracy i pomocy wzajemnej. Należy zwrócić uwagę, że miało to miejsce w akurat zmienionej sytuacji wewnętrznej w bloku wschodnim. Po pierwsze, z jednej strony właściwie we wszystkich krajach bloku już umocowały się tzw. rządy ludowe, ale $\mathrm{z}$ drugiej strony zaczął pojawiać się na horyzoncie problem Jugosławii, wobec czego przyspieszenie podpisania układu polsko-rumuńskiego mogło być także odczytywane w kategoriach symbolicznych - jako manifestacja jedności obozu sowieckiego.

W pierwszym okresie po zakończeniu II wojny światowej podstawą wzajemnych stosunków pomiędzy krajami socjalistycznymi (budującymi socjalizm) była seria traktatów bilateralnych, utworzonych nieco na zasadzie starogreckiej symmachii przez poszczególnych członków obozu zarówno pomiędzy sobą, jak i oczywiście z ZSRR jako głównym spoiwem ideologicznym i gospodarczym obozu. Formalnie istotą tych układów była zasada socjalistycznego internacjonalizmu, co miało oznaczać jedność i wzajemne poparcie państw socjalistycznych na niwie międzynarodowej. Każde państwo w ramach

${ }^{11}$ L. Ci a ma g a, Polsko-rumuńska wspótpraca gospodarcza, Sprawy Międzynarodowe, 1/1961, s. 59. 
zawieranych umów miało prawo do otrzymania pomocy, ale też i jej świadczenia na rzecz innych ,zaprzyjaźnionych podmiotów” w zakresie polityki, ideologii, gospodarki i wojskowości ${ }^{12}$.

Pierwsze próby stworzenia jednolitego bloku gospodarczego państw budujących socjalizm podjęto po utworzeniu Kominformu w roku 1947. Organizacja ta miała stanowić w zamyśle Józefa Stalina organ nadzorczy nad linią polityczną i gospodarczą przyjętą i aplikowaną przez poszczególne kraje demokracji ludowej. Sankcjonowanie zasady nadzoru sowieckiego oznaczało przede wszystkim konieczność dostosowania własnej gospodarki do wzorców wschodnich, oczywiście z dozwolonymi niewielkimi różnicami. Najgroźniejszy w takim układzie był sformułowany dogmat o podziale świata gospodarczego na dwie części, z których jedna - świat zachodni nadal podlega wszelkim prawom rynku, w tym przede wszystkim kryzysom gospodarczym i innym ograniczeniom wynikającym ze stosowania zasad gospodarki rynkowej. Druga część świata natomiast - kraje bloku wschodniego tym prawidłom miały nie podlegać, miały być wolne od wszelkiego rodzaju koniunkturalnych kryzysów i prowadzić wzajemne stosunki gospodarcze w sposób korzystny dla wszystkich partnerów handlowych, co w klasycznej ekonomii wydaje się niemożliwe do osiągnięcia. Wiara w odporność gospodarki socjalistycznej na wszelkie kryzysy prawdopodobnie bazowała na doświadczeniach ZSRR w czasie Wielkiego Kryzysu, kiedy to kraj ten właściwie nie został w dużym stopniu (oficjalnie) dotknięty przez depresję - niemniej należy pamiętać, że znajdował się on wówczas w okresie forsownej industrializacji, przy minimalnym udziale w gospodarce światowej, w związku z tym i oddziaływanie nań kryzysu było znikome ${ }^{13}$. W założeniu ideologów współpracy socjalistycznej wspólny rynek socjalistyczny miał zapewnić wszystkim jego uczestnikom nieskrępowany dostęp do surowców i nieograniczone możliwości zbytu, co w teorii oczywiście było osiągalne z uwagi na kluczową rolę ZSRR jako dostarczyciela surowców i później odbiorcy produkcji. Najwyraźniej liczono wówczas na powstanie rynku zamkniętego, w pewnym sensie autarkicznego, bowiem jak się wydaje, jedynie w takim układzie mogło to w miarę skutecznie funkcjonować - zwłaszcza przy założonym niekorzystaniu z zachodniej myśli technologicznej czy zachodnich dostaw, za które przecież należało zapłacić, co z kolei powodowało odpływ walut wymienialnych ze wspomnianego obszaru płatniczego.

Istotą współpracy miały być wieloletnie układy handlowe, jak już wspomniano, zawierane pod auspicjami ZSRR. W modelowym porozumieniu tego typu przewidziano wymianę według sztywnych corocznych kontyngentów poszczególnych grup materiałowych, rozliczać się zaś miano na zasadzie clearingu, czyli okresowego wyrównywania sald handlowych. W pierwszych umowach nie liczono się z koniecznością zaspokajania potrzeb ludności, większą uwagę przykładając do zapewnienia dostaw towarów niezbędnych do szybkiej industrializacji. Co istotne, przynajmniej formalnie wyrzekano się wszelkiej dyskryminacji wobec partnerów zagranicznych mających być traktowanymi tak jak partnerzy krajowi.

12 Ibidem, s. 19.

13 Niemniej jednak należy pamiętać o olbrzymiej cenie, jaką ludność ZSRR zapłaciła za plany forsownej industrializacji kraju. Przede wszystkim trzeba wspomnieć o wielkim głodzie na Ukrainie, który oprócz wymiaru ekonomicznego miał także i wymiar polityczny, oraz o forsownej i przymusowej kolektywizacji rolnictwa. V. Gu zu n, Imperiul foamei. Foametea artificială din URSS i impactul Supra spaţiului românesc, 1921-1922, 1931-1933, 1946-1947, București 2014. 
Za nieformalnego twórcę RWPG uznaje się Nikołaja Wozniesieńskiego (1903-1950), ówczesnego szefa Państwowego Komitetu Planowania ZSRR w Moskwie. Realizował on swoją politykę ekonomiczną do roku 1949, kiedy to został zdymisjonowany i aresztowany, niemniej do tego czasu zdołał położyć podwaliny pod powojenną gospodarkę sowiecką ${ }^{14}$. Nadzorował on też zawieranie traktatów handlowych z poszczególnymi krajami satelickimi ZSRR, tworząc przez to podstawę do budowy RWPG. W węgierskim Matrahaza miały wówczas miejsce spotkania wstępne, które można uznać za przygotowanie do zawarcia układu; uczestniczyli w nich delegaci Polski, Węgier oraz ZSRR. Rumuni również nie pozostawali na uboczu wydarzeń. Sam Gh. Gh. Dej miał później utrzymywać, że inicjatywa ta była pomysłem rumuńskim ${ }^{15}$, co z pewnością było twierdzeniem na wyrost, jednak wiadomo, że oprócz spotkania na Węgrzech sprawę omawiano także, przynajmniej dwukrotnie, na tajnych posiedzeniach w Moskwie.

Na podstawie wcześniejszych ustaleń w początkach 1949 roku przystąpiono do budowy RWPG, ale od zarania widać skoncentrowanie się tej organizacji na wymianie handlowej z ZSRR, dla którego stała się ona wygodnym narzędziem kontroli gospodarczej nad pozostałymi krajami bloku wschodniego. Sprawowana była przede wszystkim za pomocą kredytów przyznawanych poszczególnym krajom, które można było spłacić właściwie jedynie przez eksport poszczególnych towarów do ZSRR, co spowodowało specyficzny układ, w którym stosunki gospodarcze z ZSRR były o wiele bardziej istotne i kluczowe niż układy z pozostałymi krajami bloku, z reguły po prostu niemającymi możliwości kredytowania i przez to budowy kolejnej warstwy stosunków ekonomicznych. W celu utrzymania organów stałych RWPG rozpisano następujący podział wydatków, który zapewne w pewnej mierze odzwierciedla relacje pomiędzy gospodarkami zainteresowanych krajów: ZSRR - 34\%, Polska - 15\%, Czechosłowacja - 15\%, Rumunia - 12\%, Węgry - $12 \%$, Bułgaria - 9\%, Albania - 3\%. Zgodnie z tym porozumieniem pierwotny budżet organizacji wynosił $6,5 \mathrm{mln}$ rubli (1949), natomiast w roku następnym wzrósł do 6,8 mln rubli, w związku z tym wpłaty obydwu krajów wyniosły odpowiednio: Rumunia (780 000 rubli - 1949; 816000 rubli - 1950), Polska (975 000 rubli - 1949 i 1020000 rubli -1950$)^{16}$.

W komunikacie o utworzeniu RWPG, który ukazał się w prasie zainteresowanych krajów 25 stycznia 1949 roku, napisano o ustaleniach narady gospodarczej, mającej miejsce w Moskwie od 5 do 8 stycznia 1949 roku. Lakonicznie wspomniano, że w wyniku rozmów powołano Radę Wzajemnej Pomocy Gospodarczej - ale nigdy nie opublikowano jej umowy założycielskiej ${ }^{17}$. Stwierdzono natomiast rozwój wzajemnych stosunków gospodarczych pomiędzy krajami bloku wschodniego, co przełożyło się na wzrost obrotów handlowych. Powstanie nowej organizacji motywowano ograniczeniami w handlu ze światem zachodnim, do jakich doszło po wejściu w życie Planu Marshalla. Zapowiedziano w związku z tym wzajemną pomoc w wymianie doświadczeń gospodarczych, dzielenie się pomocą techniczną i pomocą w handlu poszczególnymi grupami towarowymi ${ }^{18}$.

${ }^{14}$ C. B rân du şa, op. cit., s. 19; Aresztowanie Wozniesieńskiego było pokłosiem tzw. afery leningradzkiej.

15 AICB, CC al. PCR, Cancelarie, 2/1949, f. 6.

16 C. Brânduşa, op. cit., s. 21.

17 W. F ory s iń s k i, Podstawy prawne działania RWPG, Warszawa 1986, s. 12; Trybuna Ludu, 25 I 1949; Universul, 25 I 1949.

18 Trybuna Ludu, 25 I 1949. 
W swoim komentarzu redakcyjnym „Trybuna Ludu” podkreśliła konieczność wzmocnienia dotychczasowych relacji dwustronnych relacjami wielostronnymi, których doskonałą platformę miała stanowić właśnie RWPG ${ }^{19}$. Przynajmniej oficjalnie powstanie organizacji gospodarczej, będącej odpowiedzią na Plan Marshalla, zostało przyjęte z odpowiednim entuzjazmem - wiadomo, że Dej polecił odbycie serii pogadanek uświadamiających we wszystkich POP w Rumunii, podobnie zapewne było w pozostałych krajach bloku. Strona rumuńska $\mathrm{w}$ gazetach zaprezentowała utworzenie nowej organizacji w entuzjastycznym tonie, zwracając jednocześnie uwagę, iż RWPG miała stać się specyficzną tarczą obronną przeciwko oddziaływaniu Planu Marshalla na państwa socjalistyczne (chodziło tu zapewne o kompensatę utraconych korzyści handlowych z zawieszonych obrotów z krajami zachodnimi $)^{20}$. Nową organizację pojmowano także wręcz jako gwarancję niezawisłości poszczególnych krajów bloku ${ }^{21}$. Oczywiście wydaje się to propagandą, niemniej w świetle tych deklaracji można łatwiej zrozumieć późniejszy opór np. strony rumuńskiej wobec planów utworzenia jednolitego rynku pomiędzy krajami RWPG.

Jeżeli chodzi o współpracę polsko-rumuńską, to należy uznać, że w takim układzie bardzo symptomatyczne było podpisanie finalnej umowy handlowej dzień po ogłoszeniu powstania RWPG (26 stycznia 1949), co oznaczało, że współpraca powinna być definiowana i rozumiana w nowym wymiarze - wspólnoty bloku wschodniego. W komentarzach prasowych zwracała na to uwagę również strona rumuńska ${ }^{22}$. Na czele delegacji polskiej, która przybyła do Bukaresztu 24 stycznia 1949 roku, stał Józef Cyrankiewicz, ówczesny premier; znajdowali się w niej także: Zygmunt Modzelewski (MSZ), Stanisław Skrzeszewski (resort edukacji), Stefan Dybowski (resort kultury i sztuki), Jan Rabanowski (resort komunikacji) i inni ${ }^{23}$. Już dzień wcześniej o wizycie informowały gazety bukareszteńskie, które zamieściły także różne artykuły okolicznościowe, zaznajamiające czytelników z aktualnymi problemami polskimi ${ }^{24}$. Delegację przyjęto z tradycyjnym już w krajach bloku wschodniego ceremoniałem, z dużym udziałem mas. Według słów Józefa Cyrankiewicza układ miał stanowić wyraz zespalania się krajów demokracji ludowej, mających te same cele w polityce zagranicznej ${ }^{25}$. Nowa organizacja, również wspomniana w wystąpieniu okolicznościowym polskiego premiera, miała odgrywać rolę organizacji wzorcowej, ukazującej zalety współpracy blokowej, w którym to przypadku wszystkie podmioty w niej uczestniczące są traktowane jednakowo ${ }^{26}$. J. Cyrankiewicz w przemówieniu, wygłoszonym podczas powitania na dworcu w Bukareszcie, wyraził nadzieję, że zapowiedziana umowa handlowa z Rumunią przyniesie duże korzyści obu krajom we wszelkich aspektach współpracy. Zaakcentowano także zbieżność terminów: ogłoszenia powstania RWPG oraz podpisania układu o współpracy pomiędzy Polską a Rumunią. W prasie polskiej Rumunię określano wówczas jako cennego partnera ${ }^{27}$. Dla Rumunów

19 Trybuna Ludu, 26 I 1949.

20 Universul, 26 I 1949.

21 Ibidem.

${ }^{22}$ Universul, 27 I 1949. Utworzenie RWPG powinno prowadzić do wzmocnienia więzi gospodarczych pomiędzy krajami socjalistycznymi a ZSRR.

${ }^{23}$ Ich sylwetki zostały odpowiednio zaprezentowane w prasie rumuńskiej. Universul, 25 I 1949.

24 Universul, 23 I 1949; Adevărul, 21 I 1949, 22 I 1949.

${ }^{25}$ A. S ow iń s k a-Krup k a, op. cit., s. 323; Trybuna Robotnicza, 27 I 1949.

${ }^{26}$ Trybuna Robotnicza, 27 I 1949.

27 Trybuna Ludu, 27 I 1949. 
natomiast zawarcie traktatu z Polską było zakończeniem procesu kształtowania nowej rzeczywistości traktatowej (czyli między wierszami sam Gh. Gh. Dej przyznał, że był to ostatni tego typu traktat). Właściwie Dej jako jedyny stwierdził, że udział obu krajów w RWPG będzie służył, poza rozwojem wzajemnych relacji, również reorganizacji wewnętrznej polityki gospodarczej obu państw ${ }^{28}$. Obroty w handlu wzajemnym pomimo wspomnianych uwarunkowan, które w pewnym sensie je hamowały i ograniczały, bardzo szybko wzrastały. W pierwszym roku po wznowieniu stosunków handlowych - tj. w 1946 wyniosły one $6 \mathrm{mln}$ zł dew., czyli 0,6\% ówczesnych polskich obrotów handlowych, niemniej w roku 1948 wyniosły już $46 \mathrm{mln}$ zł dew., by w 1950 roku wzrosnąć do $99 \mathrm{mln}$ zł dew., czyli 1,9\% obrotów polskiego handlu zagranicznego (w udziale procentowym był to najwyższy wskaźnik obrotów, dopiero w 1971 roku handel z Rumunią przekroczył 2\% ogólnego wolumenu polskiego handlu ${ }^{29}$ ).

Strona rumuńska bardzo szybko po zasygnalizowaniu początku integracji w ramach nowej organizacji rozpoczęła wcielanie jej zarządzeń w życie. Właściwie już w połowie 1949 roku wszelki rumuński handel zagraniczny był realizowany jedynie za pośrednictwem wyspecjalizowanych central handlowych, których tworzenie zainicjowano w roku 1947 i które na przestrzeni dwóch lat zdołały całkowicie zmonopolizować rumuński handel zagraniczny. Działanie to zostało ostatecznie umocowane prawnie przez odpowiedni dekret Rady Państwa, przyznający monopol na handel zagraniczny centralom handlu nadzorowanym bezpośrednio przez Ministerstwo Handlu Zagranicznego ${ }^{30}$. W okresie późniejszym państwowy monopol handlu zagranicznego został potwierdzony konstytucyjnie w ustawach zasadniczych uchwalanych w latach 1952 i 1965.

Na II sesji RWPG w 1949 roku przyjęto tzw. zasady sofijskie, które w zamierzeniach miały ułatwić industrializację w krajach bloku. Polegały one na bezpłatnym transferze rozwiązań technicznych wewnątrz krajów bloku. Oczywiście dla krajów słabiej zaawansowanych pod względem technicznym były one do pewnego stopnia wygodne, gdyż umożliwiały właściwie bezkosztowe zdobycie rozwiązań technologicznych, natomiast z drugiej strony wstrzymywały innowacyjność bądź po prostu dążenie do podniesienia poziomu technologicznego własnych wyrobów za pomocą licencji zagranicznych - zachodziła bowiem obawa, że uzyskanymi za dewizy rozwiązaniami trzeba będzie się podzielić z pozostałymi członkami organizacji za darmo.

W kontekście handlu zagranicznego należy nadmienić, że w omawianym okresie Rumunia notowała $\mathrm{z}$ reguły ujemne saldo $\mathrm{w}$ handlu zagranicznym, przy ciągłym wzroście ogólnego wolumenu tegoż.

Generalizując: pierwszy okres funkcjonowania RWPG charakteryzował w przypadku rumuńskim przede wszystkim bardzo duży udział we wspomnianym handlu krajów RWPG, w tym i Polski, z reguły przekraczał on ponad $70 \%$ ogólnej sumy eksportu. W dobie intensywnej industrializacji i, co za tym idzie, importu rozmaitego rodzaju maszyn do Rumunii, zwłaszcza z terenów ZSRR, bardzo często przekraczał on nawet $80 \%$, rekordową wartość uzyskując w latach 1952 i 1953, kiedy to aż 84\% rumuńskiego handlu

\footnotetext{
${ }^{28}$ Adevărul, 28 I 1949.

${ }^{29}$ J. B a zg i er, M. Nite ck i, Polska - Rumunia. Gospodarka, wspótpraca, Warszawa 1973, s. 118.

${ }^{30}$ I. A le x a n d r e s c u, Politică României de lărgire şi diversificare a relaţiilor economice externe (1948-1965), Revista de Istorie, t. 31, nr 3, s. 364.
} 
Import, eksport i bilans handlowy Rumunii w latach 1948-1962/ w milionach lei

\begin{tabular}{|c|c|c|c|c|c|c|}
\hline rok & $\begin{array}{l}\text { handel } \\
\text { zagr. } \\
\text { ogółem }\end{array}$ & $\begin{array}{c}\text { wzrost } \\
\text { w stosunku } \\
\text { do } 1948 \mathrm{r} \text {. } \\
=100\end{array}$ & Eksport & import & \multicolumn{2}{|c|}{$\begin{array}{c}\text { Saldo } \\
\pm\end{array}$} \\
\hline 1948 & 1648 & 100 & 896 & 752 & + & 144 \\
\hline 1949 & 2321 & 140 & 1159 & 1162 & - & 3 \\
\hline 1950 & 2735 & 170 & 1274 & 1461 & - & 187 \\
\hline 1951 & 3216 & 190 & 1580 & 1636 & - & 56 \\
\hline 1952 & 4009 & 240 & 1826 & 2183 & - & 357 \\
\hline 1953 & 4973 & 300 & 2196 & 2777 & - & 581 \\
\hline 1954 & 4544 & 280 & 2216 & 2328 & - & 112 \\
\hline 1955 & 5301 & 320 & 2530 & 2771 & - & 241 \\
\hline 1956 & 5075 & 310 & 2661 & 2414 & + & 247 \\
\hline 1957 & 5416 & 330 & 2465 & 2951 & - & 486 \\
\hline 1958 & 5700 & 350 & 2810 & 2890 & - & 80 \\
\hline 1959 & 6146 & 370 & 3134 & 3012 & + & 122 \\
\hline 1960 & 8189 & 500 & 4302 & 3877 & + & 415 \\
\hline 1961 & 9643 & 590 & 4735 & 4888 & - & 135 \\
\hline 1962 & 10554 & 640 & 4908 & 5646 & - & 738 \\
\hline
\end{tabular}

[według:] I. Alexandrescu, Politică României de lărgire şi diversificare a relaţiilor economice externe (1948-1965), Revista de Istorie, t. 31, nr 3, s. 365.

Udział krajów socjalistycznych i kapitalistycznych w handlu zagranicznym Rumunii 1948, 1950-1962

\begin{tabular}{|c|c|c|c|c|c|c|c|c|c|c|c|c|c|c|}
\hline & $\stackrel{\infty}{2}$ & $\stackrel{\circ}{2}$ & $\check{n}$ & $\stackrel{\sim}{2}$ & $\stackrel{n}{2}$ & $\stackrel{ \pm}{2}$ & $\stackrel{n}{2}$ & $\stackrel{2}{2}$ & $\hat{n}$ & $\stackrel{\infty}{2}$ & ฉิ & 융 & 후 & గูర \\
\hline $\begin{array}{l}\text { kraje } \\
\text { socjalistyczne }\end{array}$ & 73 & 83 & 80 & 84 & 84 & 81 & 80 & 78 & 77 & 78 & 80 & 73 & 69 & 68 \\
\hline $\begin{array}{l}\text { kraje } \\
\text { kapitalistyczne }\end{array}$ & 27 & 17 & 20 & 16 & 16 & 19 & 20 & 22 & 23 & 22 & 20 & 27 & 31 & 32 \\
\hline
\end{tabular}

[według:] I. Alexandrescu, Politică României de lărgire şi diversificare a relaţiilor economice externe (1948-1965), Revista de Istorie, t. 31, $\mathrm{nr}$ 3, s. 371. 
przypadało na kraje RWPG. Jednakowoż należy wspomnieć, że w schyłkowym okresie życia J. Stalina, a jednocześnie w pierwszym okresie działania tej organizacji, jej funkcjonowanie było ograniczone z powodu stanowiska sowieckiego przywódcy, który poprzez indywidualne konsultacje preferował sprawowanie osobistej kontroli nad krajami bloku wschodniego i ich przywódcami. Alternatywnym i również często wykorzystywanym sposobem było kierowanie do poszczególnych krajów satelickich licznych misji gospodarczych i wojskowych ${ }^{31}$.

Biorąc pod uwagę wyżej zaprezentowane wskaźniki, wyraźnie widać okres intensywnej industrializacji w Rumunii oraz ograniczenie wymiany handlowej z krajami kapitalistycznymi. W ogólnym handlu generowanym przez kraje członkowskie RWPG udział rumuński kształtował się w omawianym okresie na poziomie 5-5,5\%, z tendencją wzrostową w miarę upływu czasu.

Przynajmniej początkowo RWPG udzielała realnej pomocy w procesie industrializacji krajów członkowskich, zwłaszcza tych zniszczonych przez II wojnę światową lub słabiej rozwiniętych, natomiast o wartości tej organizacji dla krajów uprzemysłowionych (Czechosłowacja, częściowo NRD) można dyskutować, szczególnie jeśli występowały problemy związane z zaopatrzeniem rynku rolnego, na rozwiązanie których z pewnością liczyły oba te kraje. Jednakże generalnie spodziewano się, że dzięki wspólnemu działaniu uda się osiągnąć pewną pozycję w handlu światowym. Rumunia była zainteresowana uczestnictwem w Radzie i bardzo szybko stworzyła odpowiednie komisje rządowe do takiej współpracy (20 X 1950); komisja była podporządkowana Radzie Ministrów, natomiast jej nazwy wielokrotnie się zmieniały, w interesującym nas okresie na jej czele stali: Miron Constantinescu i Alexandru Bârlădeanu (do 1965 roku).

W ramach RWPG Rumunia jako kraj założycielski opowiadała się za (z oczywistych uwarunkowań względną) wolnością kształtowania własnej polityki ekonomicznej. Zdecydowanego poparcia udzielano wszelkim próbom poszerzenia organizacji o kolejne kraje członkowskie, zwłaszcza proweniencji socjalistycznej32. Opowiadano się za swobodnym dostępem do surowców naturalnych oraz za pełną równością w odniesieniu do stosunków wzajemnych. W największym stopniu zwracano uwagę (przynajmniej pod względem propagandowym) na konieczność zapewnienia zrównoważonego wzrostu gospodarczego we wszystkich krajach członkowskich oraz poprawy stopy życiowej we wskazanych krajach.

Pod względem organizacyjnym szczególną rolę przydawano cyklicznym spotkaniom liderów poszczególnych partii robotniczych/komunistycznych z krajów członkowskich. $\mathrm{Na}$ wspomnianych zebraniach podejmowano (raczej zatwierdzano) decyzje dotyczące dalszego rozwoju organizacji. W interesującym nas okresie (czyli do roku 1962) uwage badaczy w największym stopniu przyciągnęły następujące zebrania: przede wszystkim konferencja, która odbyła się w maju 1958 roku i na której podkreślono konieczność powiązania partykularnych planów gospodarczych z ogólną wizją rozwoju stosunków na forum RWPG. Wskazując na konieczność koordynacji planów w poszczególnych krajach Rady, tak aby zmaksymalizować benefity płynące z potencjalnej współpracy, przede

${ }^{31}$ J. Kaliński, Rubel transferowy, Kwartalnik Kolegium Ekonomiczno-Społecznego. Studia i Prace, 2013/3, s. 147.

${ }^{32}$ Przede wszystkim aktywnie wspierano przyłączenie: Albanii (1949-1962), NRD (1950), Mongolii (1962) i Kuby (1972). 
wszystkim zwrócono uwagę na konieczność zwiększenia produkcji w przemyśle maszynowym oraz w przemyśle wydobywczym i energetycznym, co miało zapewnić w największym możliwym stopniu samowystarczalność bloku. Była to ostatnia z konferencji, na których generalnie akceptowano rumuńskie dążenia do industrializacji kraju.

Kolejne ważne spotkanie miało miejsce w roku następnym - 1959 - tym razem kluczową sprawą było zatwierdzenie statutu organizacji, która przez poprzednie 10 lat funkcjonowała bez tak ważnego przecież dokumentu, regulującego wzajemne układy i relacje. Konieczność podjęcia rozmów na temat utworzenia statutu Rady zasygnalizowano po raz pierwszy na X Sesji RWPG w grudniu 1958 roku w Pradze, prace nad nim trwały rok. W oficjalnym dokumencie jasno zadeklarowano: cele, główne elementy współpracy i sposoby dalszego jej rozwijania oraz strukturę organizacyjną Rady. Wspomniane najważniejsze pryncypia organizacji oficjalnie określono jako: rozwój planów ekonomicznych poszczególnych krajów członkowskich, przyspieszenie rozwoju ekonomicznego i technicznego poszczególnych krajów członkowskich, podniesienie poziomu uprzemysłowienia krajów członkowskich, zwiększenie produktywności poszczególnych krajów; wszelkie te działania miały być osiągnięte na drodze współpracy w ramach ruchu robotniczego. Przewidywano oczywiście współpracę ze wszystkimi krajami świata, niemniej jednak pod tym względem zwracano uwagę na pryncypium nieinterwencji w wewnętrzne sprawy poszczególnych krajów i rozwój stosunków międzynarodowych na zasadzie wzajemnego poszanowania i równości. Szczególne miejsce poświęcono zasadzie konsensusu, dotyczącej zaleceń i uchwał Rady, które miały być podejmowane jedynie za zgodą zainteresowanych krajów członkowskich Rady. Co istotne, można było odseparować się od wykonania konkretnego zalecenia i dopiero w okresie późniejszym ewentualnie dołączyć do krajów je realizujących ${ }^{33}$. Ważne, że również w roku 1959 na forum komisji RWPG do spraw rolnictwa i leśnictwa po raz pierwszy Czechosłowacja i NRD zasugerowały konieczność wprowadzenia zasad podziału i specjalizacji produkcji właśnie w tym sektorze.

W omawianym okresie finalnym aktem konstytuującym współpracę w RWPG był akt z roku 1962 - o podstawowych pryncypiach międzynarodowego podziału pracy, w którym rekomendowano przyjęcie jako podstawy do współpracy zasady koordynacji planów rozwojowych krajów członkowskich. Na spotkaniu w roku 1962 zwrócono uwagę na konieczność przyspieszenia specjalizacji i współpracy międzynarodowej w produkcji, zwłaszcza w odniesieniu do różnego rodzaju nowoczesnych rozwiązań o charakterze technicznym. Był to projekt, który wzbudził w Rumunii największe kontrowersje.

Stosunki gospodarcze polsko-rumuńskie w latach pięćdziesiątych rozwijały się nierównomiernie. Przede wszystkim negatywnym (z punktu widzenia ekonomii socjalistycznej) zjawiskiem była nadwyżka, jaką Polska notowała w przypadku handlu z Bukaresztem. Do tego niekorzystnego, z uwagi na charakter rozliczeń i w sumie fikcyjną wartość waluty, zjawiska doprowadziły nieporozumienia na niwie gospodarczej, dotyczące wolumenu towarów, jakie miały być przedmiotem wymiany handlowej pomiędzy zainteresowanymi krajami. Rumunia odmawiała bowiem sprzedaży do Polski towarów, na których Warszawie w sumie najbardziej zależało, czyli ropy naftowej i zboża. Można wskazać przynajmniej dwa potencjalne wytłumaczenia tej sytuacji. Po pierwsze zapewne rolę odgrywały

${ }^{33}$ R. Skobelski, PRL w Radzie Wzajemnej Pomocy Gospodarczej w latach 1956-1970, Kwartalnik Historyczny, 2007, nr 3, s. 58; T. D or ot a, B. R e u tt, op. cit., s. 12. 
tu wciąż duże dostawy ropy do ZSRR, a także świadomość ograniczonych już zapasów tego surowca na rumuńskich polach naftowych. Z tych powodów Rumunia odrzuciła w 1957 roku polską propozycję zawarcia wieloletniej umowy odnośnie do sprzedaży ropy naftowej ${ }^{34}$. Oczywiście należy sobie zadać kluczowe pytanie, czy była to jedynie decyzja rumuńska, czy też do odmowy przyczynili się Sowieci, którzy właśnie rozpoczynali pracę nad budową rurociągu Przyjaźń i nie na rękę była im dywersyfikacja dostaw ropy przez Polskę. Wspomnianą zależność Polski od ZSRR widać wyraźnie podczas analizy danych dotyczących wspomnianego sektora handlu, gdyż w okresie 1955-1960 udział ZSRR w dostawach ropy do Polski wyniósł średnio 95\%, przy czym w ostatnich dwóch latach $(1959,1960)$ osiągnął poziom $100 \%{ }^{35}$. Podobnie w okresie późniejszym kształtował się udział procentowy dostaw radzieckiej ropy naftowej do wszystkich krajów RWPG, który osiągnął poziom 100\%, czyli Rumunia nie miała możliwości eksportu własnej ropy naftowej, mogąc przeznaczyć swoje wydobycie na własne potrzeby ${ }^{36}$.

W pierwszej pięciolatce (1950-1955) Rumunia oficjalnie znacząco umocniła swój potencjał gospodarczy, przynajmniej dwukrotnie zwiększając moce produkcyjne w odniesieniu do kluczowych dla przemysłu ciężkiego materiałów. W okresie 1950-1955 wzrósł również poziom wymiany międzynarodowej Rumunii, w stosunku do krajów socjalistycznych dwukrotnie, natomiast w stosunku do krajów kapitalistycznych 2,5-krotnie ${ }^{37}$.

Po zawarciu układu handlowego z Polską w styczniu 1949 roku obroty handlowe pomiędzy obydwoma państwami kształtowały się w przypadku Polski na poziomie 1,5\% ogólnego handlu zagranicznego, osiągając we wspomnianym roku wartość 73,4 mln rubli. Udział Rumunii w polskim handlu utrzymał się, przynajmniej przez 10 lat, na wspomnianym poziomie ${ }^{38}$, jeżeli chodzi o udział procentowy, natomiast jeśli chodzi o wartość bezwzględną, to należy zauważyć, że wzajemne obroty wzrosły do 1959 roku dwukrotnie $\left(155 \mathrm{mln}\right.$ rubli) ${ }^{39}$. Z kolei udział Polski w handlu rumuńskim był o wiele mniejszy (w układzie procentowym stanowił zaledwie $0,4 \%$ ), co powodowało wspomnianą już nadwyżkę, niekorzystną dla Polski we wzajemnych obrotach. W latach pięćdziesiątych rekordowy był rok 1952, kiedy to wzajemne obroty sięgnęły poziomu 104200000 rubli, co było wyjaśniane intensywną wymianą handlową, obejmującą oprócz produktów naftowych także zboże i produkty przemysłu drzewnego ${ }^{40}$. Od roku 1953 obserwowany był spadek obrotów, co początkowo tłumaczono rezygnacją z eksportu zbóż i tarcicy iglastej przez Rumunię, później doszło zaprzestanie importu przez stronę polską rudy manganowej, z uwagi na jej złe parametry ${ }^{41}$.

Intensyfikacją obrotów handlowych miała zajmować się, powołana po wizycie Gomułki w Bukareszcie, Komisja Rządowa do spraw Współpracy Gospodarczej, która po raz pierwszy zebrała się w grudniu 1958 roku. Była to instytucja uniwersalna, mająca ge-

${ }^{34}$ Historia dyplomacji polskiej, t. VI, Warszawa 2010, s. 520.

35 Rocznik Statystyczny 1961, s. 273.

${ }^{36}$ Rumunia wydobywała wówczas około $15 \mathrm{mln}$ ton ropy naftowej rocznie. T. D or ota, B. Reutt, op. cit., s. 52, 53.

${ }^{37}$ Dziś i jutro rozwoju gospodarczego Rumunii, Sprawy Międzynarodowe, 4/1956, s. 89.

38 Por. np. Rocznik Statystyczny 1955, s. 177.

${ }^{39}$ L. C i a m a g a, Polsko-rumuńska wspótpraca gospodarcza..., s. 60.

${ }^{40}$ AAN, Sekretariat KC, XIa/58 (Notatka w sprawie stosunków polsko-rumuńskich, 12 IV 1958), f. 8.

41 Ibidem, s. 9. 
neralnie koncentrować się na podniesieniu poziomu obrotów handlowych pomiędzy obydwoma zainteresowanymi krajami. Według oficjalnych dokumentów działania Komisji przyniosły skutek, do roku 1960 na tyle, że Polska zajmowała 6 miejsce wśród partnerów Rumunii w handlu zagranicznym. Eksportowano głównie produkty przemysłu maszynowego, natomiast przeważającą wartość importu stanowiły produkty naftowe (około 80\%). Były to produkty pochodne przemysłu petrochemicznego, przetworzone, niemniej jednak w pięciolatce 1955-1960 wyraźnie widać spadek importu tej grupy materiałowej, bowiem wielkość wspomniana spadła z 294 tys. ton w latach 1956 i 1957 do 190 tys. ton w roku $1960^{42}$. Prawdopodobną przyczyną tego zjawiska był jednoczesny bardzo wyraźny wzrost importu tych towarów z ZSRR.

Jednakże na przestrzeni lat pięćdziesiątych XX wieku w strukturze obrotów polsko-rumuńskich były zauważalne pewne przesunięcia, związane zwłaszcza ze zmniejszeniem udziału procentowego artykułów spożywczych, natomiast ze wzrostem wartości dóbr inwestycyjnych ${ }^{43}$. Przede wszystkim utrzymywano na stałym poziomie handel koksem, wyrobami walcowanymi i włóknami sztucznymi, natomiast starano się zwiększyć eksport maszyn i urządzeń przemysłowych - w tej grupie materiałowej wzrosty mogły sięgać nawet $100 \%$ w skali roku.

W kontekście roku 1953 Rumunia została wspomniana jako jeden z głównych dostawców artykułów rolno-spożywczych ${ }^{44}$.

W kolejnej umowie handlowej z Polską, podpisanej 13 marca 1956 roku, przewidziano oczywiście poważny wzrost wzajemnych obrotów handlowych. Polska eksportowała wtedy do Rumunii głównie: koks, wyroby walcowane, silniki do agregatów walcowniczych, walce hutnicze, transportery, sprzęt chirurgiczny, chemikalia i narzędzia; z Rumunii do Polski sprowadzano w szczególności: produkty naftowe, rudę manganową, koncentraty metali kolorowych, piryty, chemikalia, urządzenia wiertnicze, zboża i artykuły spożywcze ${ }^{45}$.

Wartość obrotów handlowych pomiędzy Polską a Rumunią w roku 1957 nie była zbyt wielka, nawet na tle pozostałych krajów bloku wschodniego, choć, co naturalne, wydaje się, że można jedynie porównywać obroty handlowe we wzajemnym obrocie pomiędzy tymi krajami z obrotami z Węgrami i Bułgarią, stosując w tym wypadku przede wszystkim kryterium geograficzne, czyli za główny wskaźnik uznając brak wspólnej granicy, co niewątpliwie utrudniało w owym czasie wymianę handlową, ponadto można za pomocnicze uznać kryterium odległości. Według danych oficjalnych, zamieszczonych w Roczniku Statystycznym w 1957 roku, obroty handlowe pomiędzy Polską a Rumunią osiągnęły wartość 130,4 mln złotych dewizowych $(32,6 \mathrm{mln} \$)^{46}$, co stanowiło 1,5\% ogólnego wolumenu polskiego handlu. Odpowiednio na przywóz towarów przypadło 62,2 $\mathrm{mln}$ zł dewizowych, co stanowiło $1,2 \%$ ogólnego handlu i $68,2 \mathrm{mln}$ zł dewizowych w przypadku wywozu, co

${ }^{42}$ Rocznik Statystyczny 1961, s. 273.

43 L. C i a ma g a, Polsko-rumuńska wspólpraca gospodarcza..., s. 61.

${ }^{44}$ Handel zagraniczny Polski Ludowej, Sprawy Międzynarodowe, 4/1954, s. 63.

${ }^{45}$ Naokoło świata. Krótki informator geograficzny, Warszawa 1957, s. 95.

${ }^{46}$ Księgowa jednostka rozrachunkowa używana w Polsce do 1982 roku dla rozliczania prowadzonych przez państwo transakcji zagranicznych oraz używana w statystykach handlu zagranicznego. Nominalnie złoty dewizowy miał odpowiadać 0,222168 gramom złota. Do 1971 roku kurs był stały: 1 złoty dewizowy $=0,225$ rubla transferowego $=0,25$ USD. Po kursie tym w latach 70. dokonywano zakupu przydziału dewiz na wyjazdy turystyczne. 
stanowiło 1,7\% w stosunku globalnym ${ }^{47}$. W obrotach handlowych Rumunii w ujęciu globalnym Polska w latach sześćdziesiątych zajmowała 8 miejsce, w porównaniu z miejscem zajmowanym $\mathrm{w}$ gospodarce innych krajów bloku był to wynik najsłabszy.

Stosunki nabrały pewnego rozpędu dopiero w roku następnym, w rezultacie wizyty, jaką Gomułka z Cyrankiewiczem złożyli w Bukareszcie w dniach 12-15 maja 1958 $\mathrm{roku}^{48}$. Choć oczywiście pod względem oficjalnym wizyta była raczej udana - dopełniono wszelkich formalności należących do nieformalnego protokołu - np. żywiołowe powitanie przez masy ludowe na trasie przejazdu, natomiast nie przyniosła wielkiego przełomu w dotychczasowych stosunkach, niemniej udało się w imię solidarności blokowej uzyskać poparcie Rumunii dla Planu Rapackiego. Zajęto także wspólne stanowisko $\mathrm{w}$ odniesieniu do ZSRR, który został określony jako pierwsze [i najpotężniejsze] państwo socjalistyczne $^{49}$, przy czym formuła ta nie wskazywała jasno na uznanie pierwszeństwa ZSRR w bloku wschodnim. Wspomniana wizyta została uznana za istotną dla dalszego kształtowania współpracy pomiędzy obydwoma krajami i niewątpliwie utorowała drogę do podpisania kolejnej wieloletniej umowy gospodarczej, regulującej wolumen handlu zagranicznego w latach 1961-1965 $5^{50}$. Jednym z wyraźnych efektów tej umowy handlowej było np. pojawienie się Rumunii w grupie dostawców produktów mięsnych do Polski; w 1960 roku import mięsa, czyli bardzo ważnego artykułu spożywczego w PRL, stanowił $11,6 \%$ ogólnej kwoty importu tej grupy towarowej. ${ }^{51}$

Istotnym sukcesem, skrzętnie podnoszonym przez dziennikarzy relacjonujących wizytę, było przekonanie Rumunów przez stronę polską do zawarcia umowy handlowej długoterminowej (do roku 1960), co stanowiło wyłom w dotychczasowej rumuńskiej praktyce zawierania umów jednorocznych. Rumunia bowiem po roku 1949 preferowała umowy jednoroczne, co umożliwiało w miarę regularną korektę cen; strona polska dla odróżnienia wolała podpisywać dłuższe umowy handlowe. Dla Rumunów były one jednak po prostu zbyt wysokie w stosunku do jakości oferowanych przez stronę polską wyrobów ${ }^{52}$. W późniejszym okresie dość częstym zarzutem Bukaresztu wobec Warszawy był wymóg strony polskiej odnośnie do sprowadzania przez zamawiającego potrzebnych komponentów z Zachodu i dostarczenia ich w celu montażu do Polski - oczywiście chodziło o ograniczenie kosztów strony polskiej. W komentarzach prasowych widać było nadzieję na podpisanie umów dotyczących przede wszystkim handlu gazem ziemnym i ropą naftową ${ }^{53}$. W tym okresie kolejnym częstym zarzutem strony rumuńskiej pod adresem Polski był swoisty manicheizm stosowany wobec kontrahentów. Jednakże wynikał

47 Rocznik Statystyczny 1957, s. 274.

${ }^{48}$ Oficjalne zaproszenie Rumuni wystosowali 11 IV 1958. AAN, Sekretariat KC, XIa/58, f. 5.

49 Trybuna Ludu, 16 V 1958.

${ }^{50}$ Było to novum w rumuńskiej polityce gospodarczej, dotąd bowiem Rumuni starali się opierać stosunki handlowe z innymi krajami na umowach jednorocznych. Miało to miejsce np. w roku 1957, Rumuni motywowali wówczas swoje negatywne stanowisko niemożnością określenia własnych możliwości eksportowych w perspektywie 3 lat. Późniejsza zmiana stanowiska Bukaresztu wiązała się z realizacją zaleceń RWPG, sugerującej zawieranie umów wieloletnich i zgodnych z perspektywami planów w krajach członkowskich. AAN, Sekretariat KC, XIa/58, f. 13, 15; E. Gla ze r, Polityka zagraniczna Rumuńskiej Republiki Ludowej, Sprawy Międzynarodowe, 11/1960, s. 48.

${ }^{51}$ Rocznik Statystyczny 1961, s. 275.

${ }^{52}$ L. Ț̆ ăr a nu, România în consiliul de Ajutor Economic Reciproc, Bucureşti 2007, s. 144.

${ }^{53}$ Trybuna Robotnicza, 15 V 1958. 
on ze specyfiki obrotów i handlu pomiędzy Polską a Rumunią, w którym notowano dużą nadwyżkę eksportu po stronie polskiej, co w swoistości handlu w ramach RWPG oznaczało z reguły stratę finansową. Dualizm relacji polegał na tym, że żądano od Rumunów, by dopominali się za sprzedane towary cen światowych (czyli aktualizowanych na bieżąco), natomiast $\mathrm{z}$ drugiej strony wymagano, by towary polskie były pozyskiwane według cen RWPG, czyli zamrożonych na lat 5, natomiast nie było to opłacalne dla Bukaresztu ${ }^{54}$, ponieważ ceny towarów przemysłowych z reguły spadały ${ }^{55}$. Co zrozumiałe, oficjalnie nie podnoszono tych problemów, twierdząc, że wszelkie trudności gospodarcze wynikają z niekorzystnego układu cen na rynkach światowych, co oczywiście nie znajduje żadnego odbicia na stosunkach wewnątrz RWPG. Gomułka w oficjalnych wystąpieniach zachwalał dobrodziejstwa, jakie miały dawać polskiemu rynkowi tzw. ceny-stop, podczas gdy to właściwie one generowały niekorzystną sytuację handlową pomiędzy Rumunią a Polską ${ }^{56}$.

W pewnym stopniu naprzeciw tym oczekiwaniom wychodziła kolejna wieloletnia umowa handlowa, zawarta 28 maja 1960 roku na lata 1961-1965; planowano wówczas, że w porównaniu z poprzednią pięciolatką wzrost wzajemnych obrotów wyniesie $65 \%{ }^{57}$. Spodziewano się to osiągnąć, między innymi, dzięki budowie na terenie Rumunii w pełni wyposażonych zakładów przemysłowych w ramach kooperacji wewnątrz RWPG - i tak od 1958 roku Polska uczestniczyła w stawianiu kombinatu celulozowego w Brăile, co naturalnie podnosiło wartość inwestycji polskich w Rumunii oraz dodatnio wpływało na wysokość wzajemnych obrotów finansowych. Relacje polityczne pomiędzy obydwoma krajami z reguły uznawano za dobre, w rozmowie z Antoninem Novotnym Gh. Gh. Dej miał określić stosunki polsko-rumuńskie jako adekwatne pod względem jakości do stosunków z ZSRR.

W latach sześćdziesiątych próbowano w polskiej polityce zagranicznej wykorzystać ustalenia podjęte na XXII Zjeździe KPZR (1961) oraz na II Międzynarodowej Naradzie Partii Komunistycznych i Robotniczych (XI 1960), w których wskazując na kierowniczą rolę KPZR, wspominano także o konieczności integracji gospodarczej krajów bloku wschodniego. Próbując zaadaptować rzeczywistość do wspomnianych wymogów, na XV Sesji RWPG w Warszawie (XII 1961) przyjęto dokument zatytułowany Podstawowe zasady międzynarodowego socjalistycznego podziału pracy; zdystansowano się w nim od dotychczas promowanych zasad, że w ramach bloku potrzebny jest autarkiczny rozwój. Działania podjęte w myśl tej inicjatywy miały umożliwić zmniejszenie dysproporcji rozwoju pomiędzy poszczególnymi krajami oraz zintensyfikować inwestycje w kluczowym

${ }^{54} \mathrm{Na}$ ten aspekt stosunków handlowych z Polską Rumuni zwracali uwagę jeszcze na XVII Sesji RWPG [XII 1962], wskazując Polskę jako kraj najczęściej łamiący zasady koordynacji cen w handlu zagranicznym. AAN, Polska Zjednoczona Partia Robotnicza. Komitet Centralny w Warszawie, Kancelaria I Sekretarzy KC PZPR [dalej: Sekretariat KC], XIa/95, f. 249.

${ }_{55}$ L. Țăra nu, op. cit., s. 145.

${ }^{56}$ W. Gomułka, I. Loga-Sowiński, S. Jędrychowski, O sytuacji gospodarczej $i$ zadaniach w 1963 r., Warszawa 1962, s. 14.

${ }^{57} \mathrm{O}$ wiele bardziej optymistycznie na tę kwestię zapatrywał się W. Gomułka, który na wiecu w Warszawie, przy okazji wizyty w Polsce delegacji rumuńskiej, zapewnił, że wzajemne obroty wzrosną w wyniku wspomnianej umowy ponad dwukrotnie, w porównaniu z okresem 1955-1960. Największe rezerwy w możliwości szybkiego podniesienia wolumenu wzajemnych obrotów upatrywano w dostawach maszyn i urządzeń produkcyjnych - z dotychczasowych 18,6\% wartości obrotów, w nowej 5-latce miały one generować nawet 50\% wzajemnych obrotów. W. Go mułk a, Przemówienia 1961, Warszawa 1962, s. 278. 
obszarze surowcowym. Najistotniejsze dla przyjęcia uchwał według wytycznych zaznaczonych w tym dokumencie okazały się Polska i Rumunia, które, co prawda z problemami, nawiązały współpracę w celu zabezpieczenia własnych interesów. Oba kraje miały wówczas podobną sytuację ekonomiczną, głównym problemem była skala wymiany pomiędzy nimi. Jednak obydwa kraje jako element wspólny, a równocześnie bardzo istotny, postrzegały kwestie sprzedaży produktów rolnych. Był to rzeczywiście obszar, gdzie mogła występować wspólnota interesów i to pomimo innej struktury rolnictwa, kolektywnej w Rumunii oraz indywidualnej w Polsce. Wynikało to $\mathrm{z}$ faktu, iż wiele produktów rolnych eksportowanych z obu krajów było pożądanych na rynkach zachodnich, co z kolei pozwalało na uzyskanie dewiz, koniecznych np. do zakupu różnych technologii przemysłowych, stąd też ewentualne wprowadzenie specjalizacji w przemyśle mogło zaburzyć ten układ, czego oczywiście obie strony sobie nie życzyły. Obawiano się, że za priorytet zostanie uznana produkcja na potrzeby RWPG, czym z kolei najbardziej zainteresowana była Czechosłowacja, której produkcja rolna $\mathrm{w}$ latach pięćdziesiątych właściwie w ogóle nie wzrosła.

Pierwsze poważne zadrażnienia w ramach RWPG pojawiły się w roku 1959, w związ$\mathrm{ku} \mathrm{z}$ dyskusją na temat statutu tej organizacji. Już wtedy ZSRR postulował wprowadzenie doń zasady podejmowania decyzji większością głosów, co potencjalnie umożliwiałoby przeprowadzanie niewygodnych dla niektórych państw układów. Rumuni, obawiając się o możliwość narzucenia im niedogodnych rozwiązań, opowiadali się zdecydowanie za utrzymaniem zasady jednomyślności. Opór Rumunii w tej sprawie, jak i później w związku z propozycją specjalizacji, wynikał też z chęci utrzymania założeń kolejnego planu gospodarczego, który miał być realizowany w latach 1960-1965. W kwestii dalszego rozwoju gospodarczego krajów bloku rozpatrywano na przełomie lat pięćdziesiątych i sześćdziesiątych przynajmniej trzy założenia:

- forsowną industrializację na poziomie całego obozu socjalistycznego;

- specjalizację w produkcji rolniczej, również na poziomie całego obozu;

- podporządkowanie specjalizacji technicznej właśnie tym krajom, które były w największym stopniu zindustrializowane ${ }^{58}$.

Po raz pierwszy możliwość druga została poddana dyskusji w roku 1959 na spotkaniu komisji RWPG, najmocniej wspierały tę ideę, jak się należało spodziewać - Czechosłowacja i NRD, rumuńscy delegaci byli wobec niej, co zrozumiałe, bardzo sceptyczni i niemal automatycznie ją odrzucali. Wskazywano wówczas, że nie można odgórnie nakazać poszczególnym krajom, co mają produkować na wsi, z uwagi choćby na różne warunki klimatyczne i wzrastające potrzeby populacji - z tego powodu, co podkreślali Rumuni, potrzebna był raczej produkcja rolna o charakterze uniwersalnym.

W 1962 roku strona polska podjęła szeroko zakrojoną akcję, mającą na celu doprowadzenie do reorganizacji RWPG i przyspieszenie procesu integracji. W tym przypadku główne decyzje były podejmowane w gronie partyjnym, a MSZ był tylko jednym z narzędzi realizacji tej polityki. Pierwsze postanowienia we wspomnianej sprawie zapadły prawdopodobnie jeszcze w końcu roku $1961^{59}$, przy czym pierwotne projekty strony polskiej,

58 S. B orşa, Chestiunea specializării în cadrul CAER (1959-1963). O Românie agrară sau una industrializată, Studia Securitatis, 1/2012, s. 102.

${ }_{59}$ W relacji Henryka Różańskiego, natenczas zastępcy przedstawiciela PRL w RWPG, już na przełomie 1961/1962 ówczesny wicepremier - Piotr Jaroszewicz miał w trakcie przekazywania instrukcji działania wspom- 
konsultowane jedynie z ZSRR, miały być na tyle daleko idące, że wywołały szok nawet w ZSRR ${ }^{60}$. Zgłaszając projekt, strona polska dość aktywnie opowiadała się za przyspieszeniem integracji w łonie RWPG, nawet za przekształceniem jej w organizację ponadnarodową. Propozycje te zostały skonkretyzowane w dokumencie z 31 I 1962, zatytułowanym Uwagi w sprawie dalszego rozwoju wspótpracy gospodarczej pomiędzy krajami $R W P G^{61}$, zaś ostateczną wersję polskiej koncepcji przedstawiono 5 III 1962 roku w dokumencie Aktualne problemy rozwoju współpracy gospodarczej krajów RWPG ${ }^{62}$. Potrzebę zacieśnienia współpracy motywowano przede wszystkim szybkim rozwojem gospodarczym krajów organizacji, do którego nie pasowała dotychczasowa jej struktura. Zakładano, że w większości krajów członkowskich w najbliższych 20 latach poziom życia się wyrówna, dlatego by ułatwić realizację tego postulatu, należy w pewnym stopniu przepracować dotychczasowe zasady działania ${ }^{63}$. Ważne było wskazanie na konieczność koordynacji działań w celu przyspieszenia eksploatacji bazy surowcowej, co jednak wymagało zwiększenia poziomu kooperacji pomiędzy krajami członkowskimi, a także często inwestowania w bazę wydobywczą w innych krajach RWPG, które co prawda dysponowały surowcami, ale nie miały zasobów materialnych, aby je eksploatować ${ }^{64}$. Najbardziej kontrowersyjnymi propozycjami polskimi okazały się te wspominające o konieczności specjalizacji w produkcji maszynowej i rolnictwie; spotkały się z potężną opozycją ze strony krajów słabiej rozwiniętych pod względem przemysłowym, przede wszystkim Rumunii, która obawiała się sprowadzenia jej do roli kraju rolniczego, z ograniczonymi możliwościami rozwoju industrialnego ${ }^{65}$. Oczywiście w kontekście oferty polskiej z 1962 roku pozostaje aktualne pytanie o samodzielność polskiej inicjatywy, wydaje się, że strona rumuńska doskonale zdawała sobie sprawę z tego, że W. Gomułka nie mógł zgłosić tej propozycji bez przynajmniej wstępnej akceptacji ze strony ZSRR; była to zatem specyficzna próba i zapewne reakcja na nią miała zdecydować o dalszych losach projektu. ZSRR, w sposób nieco pojednawczy starając się załagodzić sytuację, zgodził się jedynie na wspólne planowanie w formie uzgadniania partykularnych planów gospodarczych na forum RWPG, z czym i tak, jak miała pokazać praktyka, był poważny problem ${ }^{66}$. Postulaty PRL zostały przedstawione w kwietniu 1962 roku w liście skierowanym do wszystkich członków

nieć o przygotowywaniu inicjatywy podniesienia działalności $R W P G$ na wyższy poziom w celu odpowiedzi na zachodzące na Zachodzie przemiany w ramach EWG. W tej sprawie Gomułka jeszcze w 1961 r. miał odbyć odpowiednie konsultacje z Chruszczowem. Prawdopodobnie to Różański był także autorem wstępnych założeń zgłoszonej propozycji. H. Różań s ki, Spojrzenie na RWPG. Wspomnienia, dokumenty, refleksje 1949-1988, Warszawa 1990, s. 135.

${ }^{60}$ Postulowano m.in. rozwiązanie RWPG, jako organizacji nieefektywnej, i zastąpienie jej inną organizacją o zmienionych zasadach statutowych. Byłaby to także inteligentna metoda pozbycia się Albanii, która w roku poprzednim, 1961 wycofała się z prac w organizacji, na co zresztą w dyskusji nad propozycjami zwrócił uwagę Stefan Jędrychowski. Ibidem, s. 137.

${ }^{61}$ AAN, KC PZPR, Sekretariat KC, XIa/91.

62 Ibidem, f. 137-189.

${ }^{63}$ Ibidem, f. 102.

${ }^{64}$ Ibidem, f. 105.

${ }^{65}$ Historia polskiej dyplomacji, t. VI, s. 591.

${ }^{66} \mathrm{~W}$ ten sposób komentował złagodzenie projektu m.in. przedstawiciel Czechosłowacji w RWPG Josef Balabán, który uznał, że Sowieci nie podzielają polskiej oceny sytuacji w RWPG jako dojrzałej do przeprowadzenia tak szeroko zakrojonych reform. K. Ka pla n, Rada vzájemné hospodářské pomoci a Československo 1957-1967, Praha 2002, s. 90. 
RWPG; pierwotnie sugerowano, by rozmowy na temat zgłoszonego projektu przeprowadzić w maju 1962 roku w Moskwie ${ }^{67}$. Wspomniano w nim o konieczności podniesienia wzajemnej współpracy na „wyższy poziom"68. Szczegółowa propozycja została zawarta w aneksie do wspomnianego listu. Proponowano w nim modyfikację statutu organizacji i stworzenie kolejnego organu nadrzędnego - Rady Polityczno-Ekonomicznej, mającej za główne zadanie nadzór nad kolejnymi etapami integracji ekonomicznej, w najogólniejszych założeniach podobnej do wzorca zachodniego. Dodatkowo, co chyba było dla strony rumuńskiej najgroźniejsze, wskazano na możliwość odejścia od zasady jednomyślności we wspomnianym organie, który to pomysł już uprzednio, od końca lat pięćdziesiątych, przewijał się w rozmowach politycznych ${ }^{69}$.W finalnej, przedstawionej w lipcu 1962 roku, propozycji niejednomyślność została zrozumiana dwojako. Po pierwsze zapewne chodziło o proste głosowanie przeciw konkretnej uchwale oraz po drugie, co było, jak się zdaje, wówczas bardziej palącym zagadnieniem - rozwiązanie sytuacji, co zrobić, gdy jedno z państw członkowskich nie będzie brało udziału w konkretnej sesji RWPG - pojawił się wówczas casus Albanii ${ }^{70}$, który formalnie zagrażał prawomocności podejmowanych na sesji uchwał, gdyż dotąd obowiązywała zasada uczestnictwa wszystkich członków organizacji ${ }^{71}$. Propozycja strony polskiej zakładała możliwość procedowania przy absencji jednego lub dwóch członków organizacji.

Koordynacja planów pomiędzy poszczególnymi krajami bloku wschodniego właściwie dotąd nie istniała, ograniczała się bowiem jedynie do uzgodnienia wolumenu dostaw towarowych na własne rynki (1951-1960). Po raz pierwszy spróbowano skoordynować plany w pięciolatce 1961-1965, co miało stanowić poważny krok naprzód w dziedzinie dalszej integracji. Zauważalna $\mathrm{w}$ tym procesie była tendencja do koordynacji produkcji na niższych szczeblach.

Jednak w ostatecznym zaproszeniu zapowiadającym tematykę rozmów na spotkaniu kierownictw partii krajów członkowskich organizacji, przewidzianym na 6-7 lipca 1962 roku $^{72} \mathrm{w}$ Moskwie, przyznano, że definitywne propozycje zostały zmodyfikowane względem pierwotnego projektu uchwat ${ }^{73}$.

W samym 1962 roku strona rumuńska bardzo wyraźnie opowiedziała się przeciwko propozycji stworzenia wspólnego dla wszystkich krajów organu jednolitego planowania, blokowano także próby powoływania wspólnych organizacji gospodarczych ${ }^{74}$. Strona polska w swym planie i tak złagodziła pierwotną propozycję Chruszczowa, mówiąc nawet

${ }^{67}$ Pierwotnie Chruszczow zasugerował termin spotkania na 31 maja 1962 r., AAN, Sekretariat KC, XIa/91, f. 278. (29 IV 1962). Pierwotna data spotkania jednak nie odpowiadała np. KPCz, która zasugerowała opóźnienie rozmów o tydzień (6-8 czerwca 1962). Ibidem, f. 306-307.

68 Ibidem, f. 263.

69 Wskazano tu jednak na pewną dobrowolność w procesie podejmowania decyzji i ich realizacji, tzn. decyzje i, co zrozumiałe, ich skutki miały dotyczyć jedynie tych krajów, które je zaaprobowały. AAN, Sekretariat $\mathrm{KC}, \mathrm{XIa} / 91$, f. 107.

${ }^{70}$ AAN, Sekretariat KC, XIa/95, f. 95.

71 Uściślał to rozdział IX, art. 18 statutu RWPG z 1958 r.

72 AAN, Sekretariat KC, XIa/91, f. 263-264 (list do przywódcy Rumuńskiej Partii Robotniczej, Gh. Gh. Deja i premiera Rumunii Iona Gh. Maurera, 10 IV 1962).

${ }^{73}$ Ibidem, f. 331 (list do przywódcy Rumuńskiej Partii Robotniczej, Gh. Gh. Deja i premiera Rumunii Iona Gh. Maurera, 15 V 1962).

74 J. Karlińs ki, Rubel transferowy, s. 148. 
o możliwości budowy wspólnego rynku krajów komunistycznych. Gomułka ze swej strony wspomniał jedynie o potrzebie dalszej stopniowej integracji, co jednak nie zostało zbyt entuzjastycznie przyjęte, szczególnie przez słabiej rozwinięte kraje (Rumunię i Bułgarię). Bukareszt ze swej strony uznał tę propozycję za niekompatybilną w stosunku do swoich potrzeb - za najbardziej szkodliwe uważano postulaty podziału pracy i specjalizacji poszczególnych krajów w przemyśle lub rolnictwie.

Należy pamiętać, że właściwie propozycja z 1962 roku to de facto trzy różniące się od siebie dokumenty. Pierwszy, wspomniany już, przedstawiony w kwietniu 1962 roku w formie listu PZPR do pozostałych partii komunistycznych, został przyjęty w Rumunii z olbrzymią rezerwą, wręcz nawet niedowierzaniem, z uwagi na zauważalną dotąd wspólnotę interesów pomiędzy obydwoma krajami. Już w końcu kwietnia do Polski zaczęły zapewne spływać pierwsze uwagi i komentarze dotyczące listu/memorandum. Pod ich wpływem 2 maja 1962 roku w Biurze Politycznym PZPR odbyła się dyskusja, w wyniku której opracowano kolejny, zmieniony projekt zmian ${ }^{75}$. Drugi, właściwie nieformalny, ale już złagodzony projekt, również przedstawiony został w formie listu do RPR. W maju 1962 roku, podczas bezpośredniej rozmowy na ten temat lidera Rumuńskiej Partii Robotniczej - Gheorghe Gh. Deja z ówczesnym polskim ambasadorem w Bukareszcie - Januszem Zambrowiczem ${ }^{76}$, Dej podtrzymał swoje negatywne stanowisko wobec akceptacji koncepcji polskiej, właściwie i tak przez wszystkich postrzeganej jako inicjatywa sowiecka. Wiadomo, iż w bezpośredniej rozmowie, do której zresztą doszło po długich naciskach ambasadora Zambrowicza, Dej początkowo kluczył, powstrzymując się od udzielenia ostatecznej odpowiedzi, wyraźnie jednak szukał pretekstu do odrzucenia polskiej propozycji. Doskonałym katalizatorem takiego działania było po raz kolejny przywołanie kwestii dalszego uczestnictwa w RWPG Albanii oraz krajów pozaeuropejskich, co oczywiście mocno wykraczało poza instrukcje otrzymane przez Zambrowicza z Warszawy. Wprawdzie Zambrowicz nie mógł dyskutować tych spraw z liderem rumuńskim, jednak niewątpliwie posłał do Warszawy odpowiednią notatkę ze spotkania, co z kolei z pewnością przyczyniło się do zmiany istoty polskiej propozycji. $\mathrm{Ku}$ zaskoczeniu strony rumuńskiej na spotkaniu w Moskwie 6-7 czerwca 1962 roku przedstawiono bardzo złagodzoną propozycję ${ }^{77}$, w której w ogóle nie pojawiała się terminologia integracyjna ${ }^{78}$. Było to widoczne już w samym tytule uchwały, w którym nie znalazło się np. stwierdzenie o rozszerzeniu koordynacji planów gospo-

75 Zaniechano w nim dążenia do zmiany nazwy organizacji; proponowano coroczne spotkania Rady RWPG na najwyższym szczeblu; wprowadzenie Komitetu Wykonawczego RWPG. H. Różań s ki, op. cit., s. 152.

${ }^{76}$ Prawdopodobnie był to ten sam dokument z poprawkami zatwierdzonymi $2 \mathrm{~V}$ na spotkaniu BP PZPR. Przesłany, jak widać, zarówno do Moskwy, jak i w formie mniej oficjalnej do Bukaresztu. E. D r a g o m i r, Cold War Perceptions: Romania's Policy Change towards the Soviet Union, 1960-1964, Cambridge 2015, s. 64.

77 Wstępna wersja nowego komunikatu końcowego została opracowana przez stronę polską najpóźniej 26 V 1962 r. AAN, Sekretariat KC, XIa/95, f. 68-74. (Komunikat o naradzie przedstawicieli partii komunistycznych i robotniczych krajów członków Rady Wzajemnej Pomocy Gospodarczej).

${ }^{78}$ AАN, Sekretariat KC, ХІа/91, f. 348-360. ПОСТАНОВЛЕНИЕ, ХVI очередной сессии Совета Экономической Взаимопомощи о дальнейшем развитии и совершенствовании организации экономического сотрудничества стран-членов Совета; f. 414-429 - niekompletna wersja polska. Wersja polska cytowanego dokumentu jest o tyle ciekawa, że pokazuje pierwotny zamiar Gomułki zmiany nazwy RWPG na OWG (Organizacja Współpracy Gospodarczej), w brudnopisie wszelkie wzmianki o OWG zostały skreślone i zastąpione dotychczasowym akronimem - RWPG. 
darczych, zresztą z proponowanego tekstu uchwały zniknęła właściwie cała retoryka integracyjna ${ }^{79}$.

Gomułka w swoim przemówieniu zwrócił uwagę na fakt, iż jego uprzednie, dość radykalne (choćby w ocenie strony rumuńskiej) postulaty wynikały z obserwowanej dotychczas niewłaściwej struktury handlu w organizacji, zwłaszcza w odniesieniu do produktów przemysłu technicznego, co uniemożliwiało utrzymanie właściwego tempa industrializacji, założonego przecież w odpowiednich planach gospodarczych, względnie wymuszało zakup technologii spoza bloku, co pochłaniało dewizy, ponadto zaprzeczało idei, dla której powołano RWPG. Ostateczna propozycja polska została ujęta w formie czterech postulatów:

- systematycznej organizacji zebrań reprezentantów krajów członkowskich RWPG, mających dyskutować o bieżących problemach ekonomicznych;

- wprowadzenia metod akceptacji wszelkich nowych postulatów i zaleceń opracowanych w RWPG;

- powszechnej akceptacji (na poziomie obozu) dokumentów wytworzonych w ramach RWPG, przy czym wspomniano także o możliwości przyjmowania rekomendacji przez poszczególne zainteresowane kraje, także w przypadku braku jednomyślności co do ich ewentualnego wprowadzenia;

- dalszego zwiększenia personelu organizacji przy zachowaniu parytetów narodowościowych tychże ${ }^{80}$.

Sam Chruszczow początkowo popierał postulaty Gomułki z listu kwietniowego, czyli te wskazujące na konieczność doprowadzenia do szerzej zakrojonej integracji. Niemniej jednak jego zdanie zostało bez zastrzeżeń poparte jedynie przez Czechosłowację i Bułgarię. Dej w swym przemówieniu silnie zaakcentował konieczność utrzymania zasady industrializacji Rumunii, nie zaś przeznaczenia jej roli państwa rolniczego. Bezpośrednio zaatakował przy tym stanowisko Czechosłowacji i NRD w kwestii uzgodnienia planów, zwłaszcza w dziedzinie koordynacji produkcji maszynowej ${ }^{81}$. Jego zdaniem pogłębiało to dotychczasowe nierówności w rozwoju gospodarczym poszczególnych państw. Ponadto w odróżnieniu od np. Gomułki dotychczasową działalność RWPG postrzegał pozytywnie, twierdząc, że powinno się jedynie dokonać pewnych usprawnień w jej działalności. Jak określił nieco eufemistycznie H. Różański w swych wspomnieniach, Dej z głęboka nieufnością odniósł się do koncepcji i referatu Chruszczowa wygłoszonego na wspomnianej konferencji. Pomimo iż konferencja z czerwca 1962 roku zakończyła się właściwie bez wiążących ustaleń, Chruszczow nadal starał się przeprowadzić swą politykę integracyjną - tym razem uwypuklając potrzebę dalszej koordynacji planów gospodarczych pomię-

79 Ibidem, f. 339-347 (Różnice pomiędzy rozesłanym projektem uchwały narady przedstawicieli partii i rządów krajów RWPG a projektem uchwały XVI nadzwyczajnej sesji RWPG). Ostateczne teksty propozycji i finalnej uchwały por.: AAN, Sekretariat KC, XIa/95, f. 2-17 [projekt] i f. 18-34 [uchwała].

80 S. B orş a, Chestiunea..., s. 105.

${ }^{81}$ Stanowisko NRD [SED], zupełnie zresztą przeciwne złagodzonej propozycji polskiej, pogłębiało nawet zastosowaną w pierwotnym projekcie retorykę integracyjną [list sekretarza SED, W. Ulbrichta do W. Gomułki z 29 maja 1962 - Propozycje delegacji NRD uzupetnień $i$ zmian do projektu uchwaty narady przedstawicieli komunistycznych i robotniczych partii i rządów krajów wchodzacych w skład Rady Wzajemnej Pomocy Gospodarczej w sprawie dalszego rozszerzenia koordynacji planów gospodarczych, budownictwa inwestycyjnego, nowej techniki i współpracy gospodarczej pomiędzy krajami członkowskimi RWPG], f. 380-394. 
dzy krajami bloku. Następna próba zaakcentowania działalności prointegracyjnej miała miejsce w listopadzie 1962 roku, gdy na kolejnym plenum KP KPZR Chruszczow ponownie zasygnalizował potrzebę powołania komórki nadzorującej jednolite planowanie na poziomie całego bloku wschodniego. Strona rumuńska ostro przeciw temu zaprotestowała i w rezultacie wszelkie próby powołania takiej komórki były torpedowane już w zalążku ${ }^{82}$. Odtąd przez długi czas Rumuni blokowali wprowadzanie do oficjalnych komunikatów z kolejnych sesji organizacji jakichkolwiek wzmianek na temat integracji pomiędzy krajami członkowskimi bloku wschodniego, zaś dla Deja pojęcie integracja miało być od tej pory synonimem wspólnego planowania, zagrażającego suwerenności Rumunii i prawu do własnego planowania rozwoju kraju ${ }^{83}$.

Co więcej, w okresie późniejszym Rumuni podkreślali, że ich postulaty przeszły dlatego, że otrzymali w negocjacjach wsparcie strony polskiej, do której potem dyplomatycznie przyłączył się i ZSRR. Zgodnie z przewidywaniami dość mocno za retoryką integracyjną opowiadała się Czechosłowacja, która spodziewała się zyskać na wprowadzeniu wspólnych zasad planowania, zwłaszcza w dziedzinie rolnictwa w ramach RWPG ${ }^{84}$. W tej mierze właściwie nawet podejrzewano, że za wspomnianą propozycją zacieśnienia współpracy powinna raczej stać akurat Czechosłowacja bądź NRD, czyli kraje jak na warunki bloku wschodniego mocno zindustrializowane, a nie Polska, która jeszcze wiele zagadnień związanych z procesem uprzemysłowienia miała przed sobą i była wciąż dość mocno zależna od produkcji rolnej. Ostatecznie utrzymano dotychczasowe zasady planowania w RWPG, przy czym według Deja dość zaskakująca zmiana stanowiska Gomułki nastąpiła po rozmowie tegoż z Chruszczowem, który zbyt entuzjastycznie początkowo podchodził do zagadnień integracyjnych, co z kolei miało wzbudzić czujność polskiego lidera ${ }^{85}$.

O ile w przypadku PRL opór wobec propozycji de facto sowieckich nie niósł większych konsekwencji, o tyle w przypadku rumuńskim sytuacja była diametralnie inna. Stanowiło to doskonały pretekst, by jeszcze mocniej akcentować rumuńską (narodową) drogę do socjalizmu. W rezultacie konflikt o podłożu ekonomicznym powoli zyskał także przesłanki polityczne, zwłaszcza że Rumunia starała się podtrzymywać dobre stosunki z ChRL i Jugosławią jako możliwymi alternatywami wobec ZSRR. Oczywiście na zaakcentowanie własnej drogi do socjalizmu w przypadku Rumunii nie wpłynęła jedynie kwestia zacieśnienia współpracy na forum RWPG. Dej już wcześniej zapewne poszukiwał takiej okazji i w miarę możliwości przygotowywał sobie grunt do tego typu przemian, np. stopniowo usuwając ze swego otoczenia ludzi bezpośrednio związanych z Moskwą i zastępując ich rodzimymi komunistami rumuńskimi, najlepiej z pokolenia młodszego i powiązanych bezpośrednio z nim - stąd też przyspieszenia nabrała kariera Nicolae Ceauşescu. Przykładem osób zagrażających potencjalnie Dejowi i w związku z tym usuniętych z partii są np. Ana Pauker i Iosif Chişinievski. Proces Pauker był zapewne przygotowywany jeszcze na początku lat 50., niemniej jednak Dej ostatecznie nie zdecydował się na postawienie jej przed sądem, jak się wydaje, nie uważał jej za bezpośrednie zagrożenie, tak jak miało to miejsce w przypadku Lucreţiu Pătrăşceanu, który mógł być postrzegany jako potencjalny

\footnotetext{
${ }^{82}$ H. Różańs ki, op. cit., s. 166.

${ }^{83}$ Ibidem, s. 161.

${ }^{84}$ L. Țăr a nu, op. cit., s. 151.

${ }^{85}$ Ibidem.
} 
następca Deja - w związku z czym został zamordowany w 1954 roku. Poczucie względnej niezależności Deja z pewnością zostało wzmocnione przez wycofanie się Armii Czerwonej z terenu Rumunii, co nastąpiło w okresie od 15 czerwca do 15 sierpnia 1958 roku $^{86}$. Sama ewakuacja została zaaprobowana $w$ trzech fazach: oficjalnej propozycji ZSRR (17 kwietnia 1958), zgody ze strony Bukaresztu na wycofanie obcych wojsk z terenu Rumunii, z jednoczesnym solennym zapewnieniem, że armia rumuńska będzie w stanie obronić zdobycze socjalizmu w swoim kraju, a ostatnim akordem było zatwierdzenie wspomnianej decyzji przez Polityczny Komitet Konsultacyjny Układu Warszawskiego (24 maja 1958) ${ }^{87}$. Ponadto należy pamiętać, że Rumunia w czerwcu 1960 roku przyjęła założenia kolejnego sześcioletniego planu gospodarczego oraz plany perspektywicznego (15-letniego), których założenia trzeba by było zmieniać w razie zaakceptowania propozycji strony polskiej, co z pewnością byłoby poważnym ciosem od strony propagandowej. Głównym priorytetem wskazanym w dokumentach III Zjazdu Rumuńskiej Partii Robotniczej była dalsza forsowna industrializacja kraju, co zrozumiałe, dokonywana przede wszystkim za pomocą przemysłu ciężkiego ${ }^{88}$. Kwestią usztywniającą stanowisko Bukaresztu w tej sprawie było wykazane w latach 1955-1960 zahamowanie tempa przyrostu dochodu narodowego Rumunii w latach 1955-1960, które w porównaniu z okresem wcześniejszym spadło niemal dwukrotnie - z 13,9\% do 7\%, według wskaźników oficjalnych ${ }^{89}$. Szczególnie niskie było ono w grupie rolnej, gdzie roczny przyrost dochodu spadł z 10,4\% do $0,8 \%$. Rodziło to zapewne obawy o dalszy rozwój i w związku z tym jakiekolwiek odgórne narzucanie Rumunii drogi, jaką ma podążać jej gospodarka, siłą rzeczy musiało wzbudzać poważne obawy, zwłaszcza że z analizy nakładów finansowych wynika, że Rumuni w odnośnym okresie (1955-1960) zainwestowali o wiele więcej pieniędzy w przemysł, niż miało to miejsce w okresie poprzednim ${ }^{90}$.

Sam odbiór propozycji polskiej, choć oczywiście przez wszystkich właściwie definiowanej jako sowiecka, na spotkaniu, które odbyło się w Moskwie w roku następnym, tj. 1963, był różnorodny; zgodnie z oczekiwaniami szczególnie entuzjastycznie o planie podziału pracy wypowiadali się przedstawiciele NRD i Czechosłowacji, akceptujący właściwie bez zastrzeżeń przedstawioną propozycję ${ }^{91}$. Na drugim biegunie zauważalna była wypowiedź delegatów polskich - wicepremiera Piotra Jaroszewicza - który dość oględnie mówił o projekcie, niemal nie zauważając, że de facto była to polska inicjatywa. Jaroszewicz w sposób wyraźny osłabiał wymowę uprzedniej polskiej propozycji, twierdząc, że owszem planowanie jest potrzebne, jednakowoż nie we wszystkich gałęziach gospodarki. Właściwie w opinii polskiego polityka wspólne planowanie powinno

${ }^{86}$ Dej przekonywał Chruszczowa powoli do tego kroku, paradoksalnie poprzez oficjalne akcentowanie dalszej potrzeby stacjonowania wojsk sowieckich w Rumunii, przynajmniej tak długo, jak istnieje NATO. J. Granville, If we don't do a u-turn now, All is lost, Gheorghiu Dej's gambit for Romanian independence from Moscow, Etudes balkaniques, XLV, 2009, 1, s. 65.

${ }^{87}$ C. Olt e an u, Al. Du ţu, C. Anti p, România şi Tratatul de la Varşovia. Istoric. Mărturii. Documente. Cronologie, Bucureşti 2005, s. 39.

${ }_{88}$ M. Croitor, S. B orşa, Triunghul suspiciuni, Gheorgiu-Dej, Hruşciov şi Tito (1954-1964), vol. I, Cluj-Napoca 2014, s. 88.

89 J. B a zg i er, M. N it e cki, Polska-Rumunia. Gospodarka, wspótpraca, Warszawa 1973, s. 29.

90 Ibidem, s. 30.

91 K. Kapla n, op. cit., s. 97. 
dotyczyć przede wszystkim towarów dostępnych na rynku międzynarodowym, natomiast w przypadku wszelakiej produkcji na rynek wewnętrzny powinien obowiązywać jedynie plan wewnętrzny konkretnego państwa, w którym dany towar był wyprodukowany ${ }^{92}$.

Konkludując, należy zauważyć, że współpraca gospodarcza pomiędzy Polską a Rumunią w okresie przed 1962 rokiem nie była zbyt intensywna, z uwagi na podobny wolumen materiałów, jaki oba kraje mogły sobie zaoferować, do tego dochodziła jeszcze niezbyt duża popularność rumuńskich i wzajemnie polskich produktów na odpowiednich rynkach w handlu detalicznym. Na stosunkowo niski poziom obrotów handlowych pomiędzy obydwoma krajami wpływał także brak porozumienia co do sprzedaży przez Rumunię do Polski głównego produktu, na który liczyła strona polska, czyli ropy naftowej. Motywy takiego działania były, jak już wspomniano, różnorakie, zarówno gospodarcze jak i polityczne. Ważną cezurą we współpracy był rok 1962, czyli zgłoszenie przez Polskę postulatu zmiany dotychczasowego modelu integracji w ramach RWPG. Opór strony rumuńskiej przeciw temu rozwiązaniu, z którego zresztą Polska bardzo szybko się wycofała, posłużył potem Dejowi i jego następcy Nicolae Ceauşescu do akcentowania narodowej drogi do socjalizmu/komunizmu oraz narodowej drogi rozwoju gospodarczego, z naciskiem na przemysł. Jednocześnie należy pamiętać, że rok 1962 to także, zapewne nieprzypadkowo, początek desowietyzacji życia publicznego w Rumunii, np. wtedy doszło do wycofania języka rosyjskiego jako obowiązkowego w szkołach, a także zmiany części nazewnictwa w przestrzeni publicznej - w konsekwencji Braszow powrócił do tradycyjnej nazwy (wcześniej miasto Stalin), ponadto inaczej interpretowano historię kraju, z ograniczonym przywróceniem pamięci o pewnych politykach aktywnych w okresie międzywojennym (np. Nicolae Titulescu).

\section{Bibliografia}

Archiwalia:

Archiwum Akt Nowych. Polska Zjednoczona Partia Robotnicza. Komitet Centralny w Warszawie, Kancelaria I Sekretarzy KC PZPR, XIa/95; Sekretariat KC PZPR, XIa/91; Sekretariat KC PZPR, $\mathrm{XIa} / 58$.

Opracowania:

I. Alexandrescu, Politică României de lărgire şi diversificare a relaţiilor economice externe (1948-1965), Revista de Istorie, t. 31/1978., nr 3, s. 363-386.

J. Bazgier, M. Nitecki, Polska - Rumunia. Gospodarka, wspótpraca, Warszawa 1973.

S. Borşa, Chestiunea specializării în cadrul CAER (1959-1963). O Românie agrară sau una industrializată, Studia Securitatis, 1/2012, s. 225-234.

C. Brânduşa, Activitatea României în Consiliul de Ajutor Economic Reciproc (1949-1974), Bucureşti 2012.

L. Ciamaga, Polsko-rumuńska wspótpraca gospodarcza, Sprawy Międzynarodowe, 1/1961.

M. Croitor, S. Borşa, Triunghul suspiciuni, Gheorgiu-Dej, Hruşciov şi Tito (1954-1964), vol. I, Cluj-Napoca 2014.

${ }_{92}$ M. Croit or, S. B or şa, Triunghul suspiciuni..., vol. II, s. 223. 
L. Dologa, Sovromurile sau cum a fost parazitata economia romaneasca; http://www.ziare.com/economie/economie-politica/sovromurile-sau-cum-a-fost-parazitata-economia-romaneasca-1033079, (dostęp 11 V 2016).

T. Dorota, B. Reutt, RWPG, geneza, działalność, perspektywy, Warszawa 1972.

E. Dragomir, Cold War Perceptions: Romania's Policy Change towards the Soviet Union, 1960-1964, Cambridge 2015.

Dziś i jutro rozwoju gospodarczego Rumunii, Sprawy Międzynarodowe, 4/1956.

W. Forysiński, Podstawy prawne działania RWPG, Warszawa 1986.

E. Glazer, Polityka zagraniczna Rumuńskiej Republiki Ludowej, Sprawy Międzynarodowe, 11/1960.

W. Gomułka, Przemówienia 1961, Warszawa 1962.

Wł. Gomułka, I. Loga-Sowiński, S. Jędrychowski, O sytuacji gospodarczej i zadaniach w 1963 r., Warszawa 1962.

J. Granville, ,If we don't do a u-turn now, All is lost”, Gheorghiu Dej's gambit for Romanian independence from Moscow, Etudes Balkaniques, XLV, 2009, 1, s. 29-68.

V. Guzun, Imperiul foamei. Foametea artificială din URSS i impactul Supra spaţiului românesc, 1921-1922, 1931-1933, 1946-1947, Bucureşti 2014.

Handel zagraniczny Polski Ludowej, Sprawy Międzynarodowe, 4/1954.

Historia dyplomacji polskiej, t. VI, [red.] W. Materski i W. Michowicz, Warszawa 2010.

K. Kaplan, Rada vzájemné hospodářské pomoci a Československo 1957-1967, Praha 2002.

J. Kaliński, Rubel transferowy, Kwartalnik Kolegium Ekonomiczno-Społecznego. Studia i Prace, 2013, nr 3, s. 147-167.

M. Leczyk, Stosunki gospodarcze polsko-rumuńskie w latach 1921-1939, Zeszyty Naukowe Wyższej Szkoły Gospodarstwa Krajowego w Kutnie, 2002, nr 4, s. 33-54.

M. Marin, The Nationalistic Discourse in Communist Romania. A General Perspective, Studia Universitatis Babes Bolyai. Historia, 2/2011, s. 80-104.

A. Marszałek, Integracja ekonomiczna krajów RWPG a stosunki międzynarodowe. Geneza niepowodzenia. Łódź 1991.

Naokoło świata. Krótki informator geograficzny, Warszawa 1957.

C. Olteanu, Al. Duţu, C. Antip, România şi Tratatul de la Varşovia. Istoric. Mărturii. Documente. Cronologie, Bucureşti 2005.

Rocznik Statystyczny 1957, Warszawa 1957.

Rocznik Statystyczny 1961, Warszawa 1961.

H. Różański, Spojrzenie na RWPG. Wspomnienia, dokumenty, refleksje 1949-1988, Warszawa 1990.

R. Skobelski, PRL w Radzie Wzajemnej Pomocy Gospodarczej w latach 1956-1970, Kwartalnik Historyczny, 2007, nr 3, s. 49-90.

A. Skrzypek, Etapy rozwoju Rady Wzajemnej Pomocy Gospodarczej, [w:] 40 lat rozwoju RWPG. Ewolucja instytucji i struktur socjalistycznej integracji gospodarczej, Warszawa 1988.

A. Sowińska-Krupka, Stosunki polsko-rumuńskie 1945-1949, Warszawa 1985.

L. Țăranu, România în Consiliul de Ajutor Economic Reciproc, Bucureşti 2007.

Prasa:

Adevărul, 21 I 1949, 22 I 1949, 28 I 1949.

Trybuna Ludu, 25 I 1949, 26 I 1947, 27 I 1949, 16 V 1958.

Trybuna Robotnicza, 27 I 1949, 15 V 1958.

Universul, 23 I 1949, 27 I 1947. 
Andrzej Dubicki

Polish-Romanian collaboration within COMECON until 1962 (to XVI COMECON Session)

\section{Summary}

The Polish-Romanian cooperation which was established during the pre-bellum era, it developed on a political and economic stage in in the changed political environment. In terms of politics, the cooperation in the initial period was determined by the political agreement concluded in January 1949, while in terms of politics, the mutual relations were regulated by the COMECON concluded at that time. This organisation determined the economical contacts the economy within the member states and their foreign trade, in spite of gathering the socialist states it was in no way considered to be a monolith. Conflicts of interests arose among the industrialized countries (Czechoslovakia, Eastern Germany) and the agricultural ones (Poland, Romania, Bulgaria). The attempt at clarifying the situation and pushing the organization towards closer cooperation was found in the proposal submitted in 1962 by Władysław Gomułka, to strengthen the cooperation within the organization. It wasn't enthusiastically accepted on the part of the Romanian decedents, who wanted to maintain their own economical priorities. Apart from the easing of the Polish point of view, which was also backed by the USSR, Romanians perceived the proposal as an endangerment towards their own interests, which, in turn, became the catalyst for establishing the so called national communism, developed after 1965 by Nicolae Ceauşescu.

Key words: Poland, Romania, COMECON, economic relations. 